Article

\title{
Hygienic Condition of Different Water Sources in the Kharaa River Basin, Mongolia in the Light of a Rapid Warming Trend
}

\author{
Bolor-Erdene Ochirbold ${ }^{1,2} \mathbb{D}$, Ariuntuya Tserendorj ${ }^{1, *}$, Katja Westphal ${ }^{3,4}$ and \\ Daniel Karthe $1,4,5, *$ (D)
}

1 Engineering Faculty, German-Mongolian Institute for Resources and Technology, Nalaikh District, Ulaanbaatar 12800, Mongolia; bolorerdene.ochirbold@gmail.com

2 Oyu Tolgoi LLC, Ulaanbaatar 14240, Mongolia

3 Department Water, Environment, Construction and Safety, Magdeburg-Stendal University of Applied Sciences, 39114 Magdeburg, Germany; katja.westphal@h2.de

4 Department Aquatic Ecosystem Analysis and Management, Helmholtz-Center for Environmental Research, 39114 Magdeburg, Germany

5 Institute for Integrated Management of Matter Fluxes and of Resources, United Nations University (UNU-FLORES), 01067 Dresden, Germany

* Correspondence: ariuntuya@gmit.edu.mn (A.T.); daniel.karthe@ufz.de (D.K.)

Received: 25 September 2020; Accepted: 15 October 2020; Published: 17 October 2020

check for updates

\begin{abstract}
Mongolia is a water-scarce land-locked country, and available water resources are utilized for multiple purposes including irrigation, food preparation, drinking water for livestock and people. Limited data availability on water hygiene means that the related risks to public health are only partially understood. This is particularly problematic due to the widespread use of unimproved water sources such as surface water and water from simple shallow wells. Based on two field surveys in the Kharaa River Basin in spring 2017 and 2018, we assessed the presence and quantity of total coliforms (TC), fecal coliforms (FC), and E. coli bacteria in surface waters and wells and investigated potential linkages between temperature and hygiene. In the Kharaa River and its tributaries, TC concentrations averaged at a most probable number of (MPN) of $754 \pm 761$ per $100 \mathrm{~mL}$ and FC concentrations at an MPN of $31 \pm 33$. Only small and non-significant correlations between coliform concentrations and temperature were identified. Coliforms concentrations in wells were lower (average MPN for TC: $550 \pm 1286$, and for FC $58 \pm 253$ ). There was considerable variation between wells, with moderate but significant correlations between temperature and bacterial counts. Low water temperatures in April and May (just above freezing to less than $6.5{ }^{\circ} \mathrm{C}$ in wells and $7.5^{\circ} \mathrm{C}$ to $14.5^{\circ} \mathrm{C}$ in the river system) and the positive correlations between temperature and coliform concentrations particularly for well samples indicate that further warming is likely to increase the risks of microbiological water pollution. In the future, this should be complemented by modeling at a watershed scale. This should include the consideration of a trend towards stronger rainfall events, changes in livestock density, and urban sewage treatment and discharge, which are other likely drivers of changes in water hygiene.
\end{abstract}

Keywords: water; hygiene; total coliforms; fecal coliforms; climate change; warming; strong rainfall events

\section{Introduction}

The access to a sufficient amount of safe drinking water is considered a basic human right, and according to Sustainable Development Goal (SDG) 6 ("Clean Water and Sanitation"), the aim has been declared to provide universal access to clean drinking water and safe sanitation to the entire 
world population by 2030. Despite some progress, it currently appears unlikely that SDG6 will be fully achieved by this deadline in all countries [1]. For instance, in Mongolia in a 2019 SDG progress report published jointly by Mongolian civil society organizations, SDG 6 is the only goal for which no specific progress report is given; the percentage of the population without access to safe drinking water is still based on 2010 figures (27.4\%) [2]. An observed increase in the incidence of severe (bloody) diarrhea (from 2.0 cases per 10,000 population in 2009 to 16.1 cases per 10,000 population in 2017) is a clear sign that infections related to poor hygiene are an emerging threat to public health in Mongolia [3]. Published information on the microbiological conditions of surface waters in Mongolia is almost non-existent. In the proximity of our study region, coliform concentrations exceeding Russian sanitary standards have been described for the Selenga at the Mongolian-Russian border, which is less than $100 \mathrm{~km}$ north of our study region [4]. With a focus on water use, a survey in the peri-urban areas of Ulaanbaatar revealed that the average contamination rate of household water containers with E. coli was approx. $36 \%$ during winter and $56 \%$ in summer, with average concentrations increasing from 12.5 to 50 E. coli per $100 \mathrm{~mL}$, respectively [5]. A review study on emerging infectious diseases in Mongolia, including infections by hepatitis A, Salmonella spp. and Shigella spp., point towards a similar seasonal pattern with a peak incidence during the warmer summer months [6]. Data from Ulaanbaatar showed that about $5 \%$ of samples taken from water kiosks exceeded a concentration of $100 \mathrm{E}$. coli per $100 \mathrm{~mL}$ [5]. Hygienic risks are even greater when private wells are used for abstracting shallow groundwater, as is often the case in so-called "ger" areas (peri-urban settlement areas dominated by small houses and "gers", i.e., traditional Mongolian felt tents) located in floodplains $[7,8]$. There is not only a considerable likelihood of wells being contaminated from nearby unsealed pit latrines and animal excreta but also very little monitoring of such water sources [7-9]. It should be also noted that in most parts of Mongolia, facilities and experienced staff for detecting water-borne pathogens or water-induced infections are lacking [7], which is likely to lead to an underestimation of actual risks. Furthermore, very little is currently known about the hygienic quality of water consumed by nomads and semi-nomads living outside settlements, but reportedly high incidence rates of diarrhea indicate potential deficits in this regard [10]. A study on water management in a tourist camp located in the remote countryside provides further evidence that water hygiene may be a major problem in locations not served by adequate infrastructures [11].

For the Selenga River Basin, a recent model-driven investigation predicted that hygienically relevant surface water contamination would aggravate under the pressures of socio-economic development and climate change [12]. From different parts of the world, it has been documented that environmental and meteorological conditions (e.g., precipitation, temperature, and solar intensity) affect the growth and transport of coliforms in rivers and streams [13-15]. Cha et al. [16] found that rainfall intensity strongly influences fecal coliform concentration in a water body due to the first flush of pollution coming with runoff. Numerous studies have shown that increasing air and water temperatures may lead to the proliferation of harmful microorganisms [17-23]. Against the background of predicted changes in the context of climate change, microbiological contamination of drinking water sources in Mongolia may therefore worsen.

In Mongolia, the mean air temperature has increased by approx. $2.1{ }^{\circ} \mathrm{C}$ since the $1940 \mathrm{~s}$ and climate models predict a further acceleration of the warming trend which is approximately twice the global average warming and typical for regions with a continental climate such as Central Asia [24-26]. Climate models predict a temperature increase of approximately $2.6^{\circ} \mathrm{C}$ (B1 scenario) to $5.1^{\circ} \mathrm{C}$ (A2 scenario) for the last three decades of the 21st century as compared to the same period of the 20th century [25]. Even though there has not been a clear trend in precipitation, a slight increase is predicted for the future. Moreover, since the 1980s, a notable trend towards strong convective rainfall events and a reduction of moderate but longer-lasting stratiform rains has been observed in Mongolia; this process is expected to continue in the future [27]. Climate change affects the regional hydrology and water quality both directly and indirectly. It has, for example, resulted in the desiccation of a 
growing number of small streams, and increased pollutant concentrations during low-flow periods in major rivers [12,28-30].

While globally there is some uncertainty regarding the direct effects of warming on (drinking) water hygiene, as it may lead to increases or decreases in pathogen concentrations depending on the temperature range and microorganisms commonly found in a specific region [18-20], almost nothing is known about the impacts of climate change on water hygiene in Mongolia to this date. However, in regions currently characterized by subpolar or temperate climates, a growing frequency and intensity of extreme hydro-meteorological events [30-32] are likely to increase public health risks related to water hygiene, even in regions with highly developed water supply systems.

The aim of this study is to provide an overview of the hygienic contamination of potential drinking water sources in the Kharaa River Basin, Mongolia, and to discuss the potential of aggravating hygienic problems in the context of climate change. In particular, we focused on the linkages between water temperature and hygienic quality. Our data set was collected in 2017 and 2018, covering potential drinking water sources such as river water, household wells, water kiosks, and tap water. The proxies comprise total coliforms (TC), fecal coliforms (FC), and E. coli (EC).

\section{Methods}

\subsection{Study Site}

The Kharaa River Basin (KRB) is a 14,534 $\mathrm{km}^{2}$ subbasin of the Selenga River which ultimately drains into Lake Baikal in Russia (see Figure 1). The KRB is representative of most other subbasins of the Selenga River in terms of climate, landscapes, land use, hydrology, and environmental change [33,34].

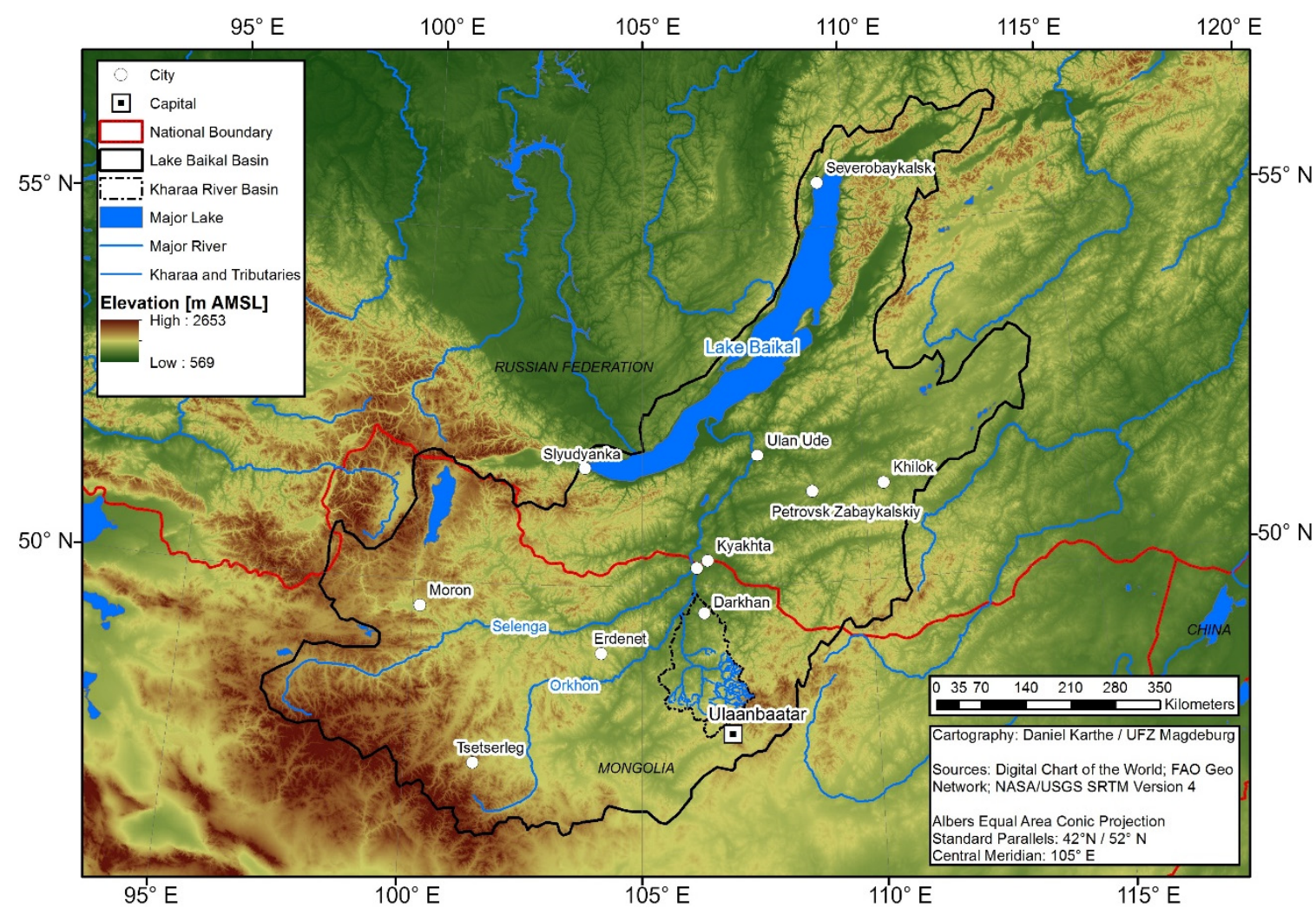

Figure 1. Location of the Kharaa River Basin within the Mongolian Plateau.

The Kharaa River Basin was selected as a model region for the implementation of Integrated Water Resources Management (IWRM) from 2007 onwards. The research presented here was conducted with the intention to improve the scientific basis for IWRM implementation in a previously data-scarce 
region [24,35]. Even though the Kharaa River Basin is very sparsely settled by international standards (approx. 10 inhabitants per $\mathrm{km}^{2}$ ), it is Mongolia's most densely settled region apart from the national capital Ulaanbaatar and its immediate surroundings. With an official population of around 75,000, Darkhan is Mongolia's third-largest city. Several smaller towns exist along the river, typically with populations of a few thousand (see Figure 2). The Kharaa and most of its tributaries have their source in the Khentii Mountains north of Ulaanbaatar. Elevations in this region partially exceed $2500 \mathrm{~m}$, but most settlements are located in the floodplains of the Kharaa. At its outlet at $654 \mathrm{~m}$ above mean sea level just north of Darkhan, the $362 \mathrm{~km}$ Kharaa River has a mean annual discharge of $12.1 \mathrm{~m}^{3} / \mathrm{s}$, albeit with large interannual variations $[24,36]$.

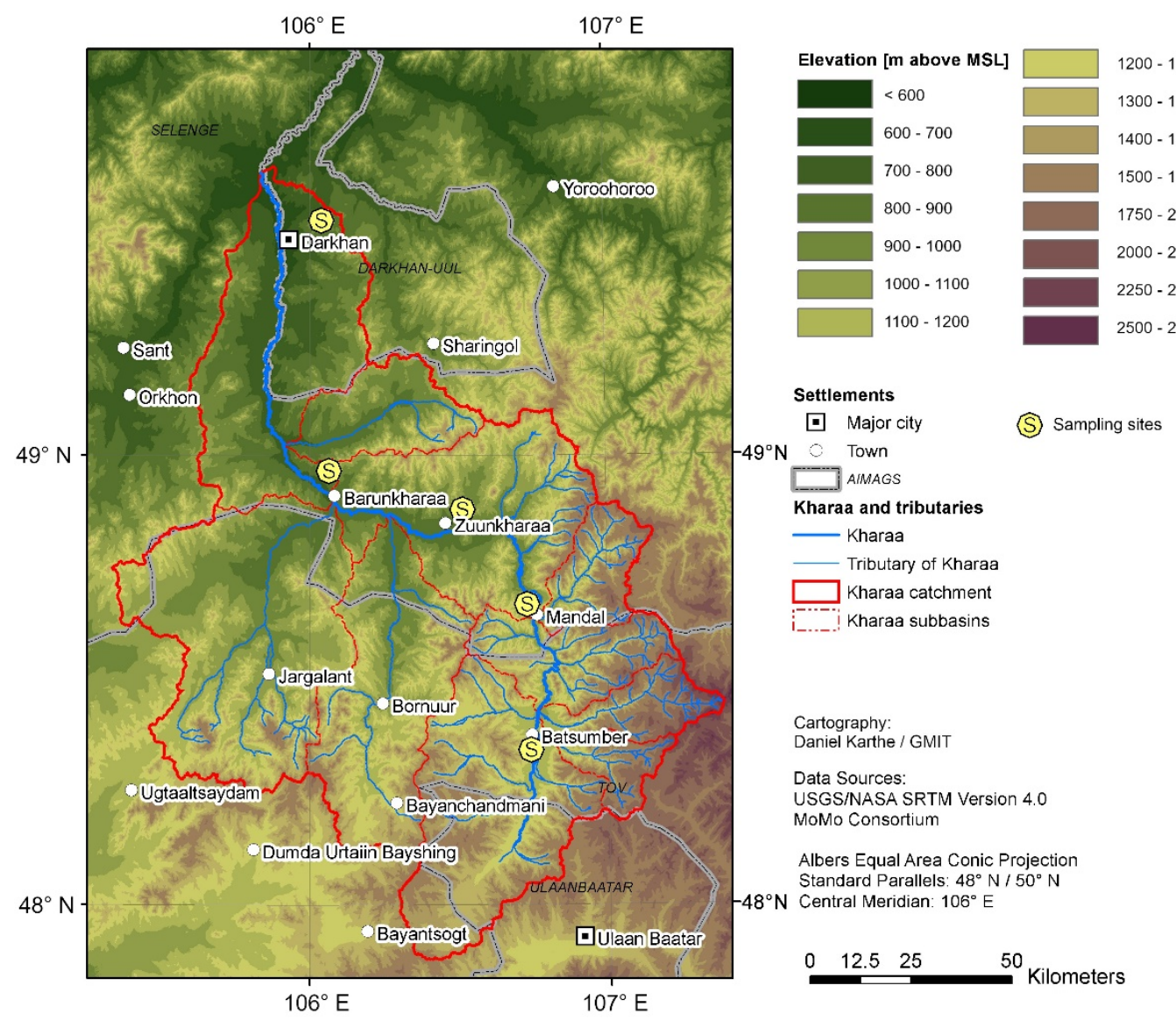

Figure 2. Location of sampling sites within the Kharaa River Basin (KRB).

Within the Kharaa River Basin, there are three principal sources for the emission of hygienically relevant microorganisms into the environment. Municipal wastewater treatment plants (WWTPs) exist in major settlements, including Darkhan, Zuunkharaa, and Baruunkharaa, and typically discharge into the Kharaa or its floodplains. WWTPs are typically based on Soviet technologies and in a poor technical state. In urban areas, approximately half of the population (those living in apartment complexes) is connected to the WTTPs [37]. The population living in peri-urban "ger areas as well as the rural population are normally not connected to central wastewater infrastructures, with unsealed pit latrines forming the dominant form of sanitation $[7,8,38]$. Another important source of microbiological water pollution is livestock. The livestock population of the Kharaa River Basin exceeds half a million heads of animals (see Table 1), which may not only defecate in or near open bodies of water but also near domestic wells $[38,39]$.

Climate change in Mongolia has been linked to various impacts on the environment [40], including glacier recession in high mountain areas [41], the degradation of permafrost [42], increasing wildfires [43], grassland degradation and desertification [44], and greater risks of droughts and 
associated livestock mortality [45]. Climate change affects the regional hydrology and water quality not only directly but also indirectly via the mentioned impacts on the environment and has resulted in the desiccation of a growing number of small streams, and increased pollutant concentrations during low-flow periods in major rivers [12,24,29].

Table 1. Composition of livestock in the KRB (in heads of the respective animal types).

\begin{tabular}{cccccc}
\hline & $\mathbf{2 0 1 4}$ & $\mathbf{2 0 1 5}$ & $\mathbf{2 0 1 6}$ & $\mathbf{2 0 1 7}$ & $\mathbf{2 0 1 8}$ \\
\hline Camel & 0.16 & 0.13 & 0.14 & 0.09 & 0.12 \\
Cow & 94.57 & 96.62 & 100.81 & 94.14 & 84.75 \\
Goat & 176.40 & 157.49 & 172.07 & 163.99 & 168.29 \\
Horse & 32.47 & 33.62 & 37.49 & 37.88 & 38.72 \\
Sheep & 277.46 & 252.36 & 276.33 & 255.06 & 247.40 \\
Total & 581.06 & 540.22 & 586.84 & 551.16 & 539.28 \\
\hline
\end{tabular}

Data are for Mandal and Bayangol Sums of Selenge Aimag and Darkhan-Uul Aimag.

\subsection{Data Collection}

Microbiological water quality is of interest when a water source is used for drinking water abstractions [46] or when water bodies are used for certain recreational purposes such as water sports [47]. Moreover, rivers are relevant as pathways for the transport of pathogenic microorganisms $[38,48]$, including antibiotic-resistant bacteria that originate from wastewater inputs containing antibiotics and their metabolites [49]. Hygienically relevant microorganisms are defined by at least one of the following criteria: (1) They are excreted by humans or animals in high doses or have low infective doses; (2) they can survive in the environment for an extended period of time; (3) they may be difficult to inactivate during water treatment [50]. Since this definition includes a large number of protozoans, bacteria, and viruses, microbiological water quality is normally assessed by a small number of easily identifiable indicator bacteria. The use of the coliform group of bacteria dates from their first isolation from feces at the end of the 19th century. Even though the definition of coliform bacteria differs slightly depending on the country or organization in charge of monitoring regulations, total, as well as fecal coliforms, are commonly used subgroups for hygienic water monitoring, as is the determination of Escherichia coli (E. coli) [50].

Water sampling was conducted in spring (mid-April to early May) of 2017 and 2018 during dry weather. At this time of the year, the ice cover on rivers has melted almost completely, and wells that were frozen during the winter continue to be used. Due to generally dry weather at this time of the year, microbiological pollution patterns are not influenced by animal feces being washed into water sources from surrounding soils. Sampling locations in the Kharaa River Basin were in or close to the following settlements: Darkhan, Baruunkharaa (also known as Bayangol), Zuunkharaa, Mandal (also known as Tunkhel), and Batsumber (see Figure 2). A total of 86 samples were taken to include surface water bodies (streams and rivers,), different types of wells (between approx. $3 \mathrm{~m}$ and $15 \mathrm{~m}$ and mostly less than $10 \mathrm{~m}$ deep), municipal tap water, and water from water kiosks where the population that is not directly connected to a piped supply system can buy water in canisters. In 2017, samples were usually taken as duplicates, and as triplicates in case of notable differences or uncertainties regarding the dilution. In 2018, single samples were taken for comparative purposes, but duplicates or triplicates were taken if deemed necessary (in case of notable deviations from 2017 values). Samples from rivers were taken about $10 \mathrm{~cm}$ below the water surface in mid-river locations with a clearly visible flow. Well water samples were taken with the container commonly used by residents after flushing it several times with fresh well water. Wells with manual or electric pumps were left running for several minutes prior to sampling.

Samples were collected in sterile single-use plastic bottles which were sealed directly after sampling and then transported to a mobile laboratory in a cooling box so that the transport time did not exceed $4 \mathrm{~h}$. Samples from taps and piped wells were taken after $5 \mathrm{~min}$ of water flow. In open wells 
and for river samples, sampling containers were fully immersed in the sample three times and rinsed with it. In the mobile laboratory, samples were screened for total coliforms (TC), E. coli (EC), and fecal coliforms (FC) using the Colilert ${ }^{\circledR}$-18 system (IDEXX Laboratories, Westbrook, ME, USA). The Colilert ${ }^{\circledR}$ system is an internationally approved standard technique for the microbiological surveillance of both drinking and surface water. Test results are not much affected by the microbial background flora, and while underestimations are possible (as with most other microbiological techniques), Colilert ${ }^{\circledR}$ is suitable for the enumeration of coliforms in different water types such as drinking water, surface water, or wastewater $[50,51]$.

For the purpose of assessing linkages between temperature and coliform concentrations, only river and well water samples were considered. Treated wastewater samples were excluded because of their specific character (higher coliform concentrations, and warmer temperatures which are presumably related to the wastewater characteristics and potential warming during the treatment process). Tap water samples as well as samples from water kiosks were also excluded because they were in most cases treated (e.g., by filtration and chlorination) and from safe sources (deep wells).

In the laboratory, samples were diluted as necessary with sterile water and thoroughly mixed with the culture substrates. Samples were then poured into the QuantiTray containers (IDEXX Laboratories, Westbrook, Maine, USA), in which they were incubated for $18 \mathrm{~h}$ at $35 \pm 0.5^{\circ} \mathrm{C}$ (for total coliforms and E. coli) and $44.5 \pm 0.2^{\circ} \mathrm{C}$ for fecal coliforms. Subsequently, the most probable number (MPN) for each sample was calculated using interpretation tables provided by the manufacturer and the IDEXX MPN Generator (Version 1.4). MPN is not a count of the actual number of indicator bacteria present in the sample but an index of the number of coliform bacteria. In addition to the water samples collected, we measured basic water quality parameters (temperature, $\mathrm{pH}, \mathrm{EC}$ ) in situ with the portable Hanna ${ }^{\circledR}$ HI 9829 multiparameter water tester (Hanna ${ }^{\circledR}$ Instruments, Woonsocket, RI, USA).

\subsection{Data Analysis}

In order to describe the general microbiological characteristics of rivers and wells, we applied basic descriptive statistics using the "pastecs" package of the software R, version 3.5.2 [52]. We additionally performed a Wilcoxon signed-rank test to assess whether river and well samples differ in their mean ranks. Our data met the assumptions of the statistical tests.

In order to investigate linkages between temperature and microbiological water quality, we characterized the relationship between water temperature and coliforms (TC, FC, and EC) for wells and rivers using linear regression of logarithmically transformed coliform concentrations versus temperature. In order to measure the strength of association between coliforms and temperature, we additionally used Kendall rank correlation as the sample size was small and coliform concentrations were not normally distributed.

\section{Results}

\subsection{Physicochemical Characteristics}

In general, all water samples tested were neutral to slightly alkaline. The groundwater-based sample types (wells, water kiosks, tap water) had a higher electric conductivity as compared to surface water. There was very little variation between samples of a single type for $\mathrm{pH}$ and electric conductivity, except for a single well in northern Darkhan which had an electric conductivity of $1528 \mu \mathrm{S} / \mathrm{cm}$. This well is located in close proximity to a channel discharging treated wastewater from Darkhan's central wastewater treatment plant into the Kharaa River. Since the sampling in 2018 was conducted, about 2 calendar weeks prior to the sampling in 2017 (starting in mid-April instead of early May), river water temperatures were slightly colder in 2018 . However, water wells were about $0.5^{\circ} \mathrm{C}$ warmer in 2018 as compared to 2017 (see Table 2). 
Table 2. General physico-chemical characteristics according to sample type (mean values).

\begin{tabular}{ccccccc}
\hline \multirow{2}{*}{ Type of Sample } & \multicolumn{2}{c}{ Temperature $\left({ }^{\circ} \mathbf{C}\right)$} & \multicolumn{2}{c}{$\begin{array}{c}\text { El. Conductivity } \\
(\boldsymbol{\mu S} / \mathbf{c m})\end{array}$} & \multicolumn{2}{c}{$\mathbf{p H}$} \\
\cline { 2 - 7 } & $\mathbf{2 0 1 7}$ & $\mathbf{2 0 1 8}$ & $\mathbf{2 0 1 7}$ & $\mathbf{2 0 1 8}$ & $\mathbf{2 0 1 7}$ & $\mathbf{2 0 1 8}$ \\
\hline River $(\mathrm{n}=17)$ & $10.3 \pm 1.9$ & $9.4 \pm 2.4$ & $227 \pm 115$ & $126 \pm 69$ & N/A & $7.9 \pm 0.4$ \\
Wastewater channel $(\mathrm{n}=8)$ & $11.9 \pm 6.5$ & $15.8 \pm 3.3$ & $1083 \pm 394$ & $1120 \pm 345$ & N/A & $8.1 \pm 0.2$ \\
Household well $(\mathrm{n}=32)$ & $3.6 \pm 1.2$ & $2.4 \pm 1.2$ & $502 \pm 324$ & $314 \pm 69$ & N/A & $7.7 \pm 0.3$ \\
Other well $(\mathrm{n}=4)$ & $4.3 \pm 0.4$ & $4.0 \pm 0.5$ & $418 \pm 60$ & $320 \pm 41$ & N/A & $7.7 \pm 0.1$ \\
Water kiosk $(\mathrm{n}=8)$ & $6.2 \pm 1.3$ & $7.3 \pm 1.6$ & $543 \pm 246$ & $391 \pm 170$ & N/A & $7.8 \pm 0.4$ \\
Tap water $(\mathrm{n}=8)$ & $13.5 \pm 9.4$ & $13.0 \pm 5.8$ & $471 \pm 64$ & $423 \pm 76$ & N/A & $7.6 \pm 0.1$ \\
\hline
\end{tabular}

\subsection{General Microbiological Characteristics}

For both years, all river, wastewater, and livestock well samples were tested positive for total coliform bacteria, and almost all samples also contained E. coli as well as fecal coliforms. Even though the majority of household wells also contained total coliforms, E. coli and fecal coliforms were only detected in some cases. Approximately one-quarter of the water kiosks and household tap water samples contained total coliforms but in most cases, no other indicator bacteria (Table 3). The previously mentioned household well which showed a very high electric conductivity (which might be interpreted as a sign of pollution by the nearby wastewater channel) was tested positively for TC (MPN 231 per $100 \mathrm{~mL}$ ) and EC (MPN 10 per $100 \mathrm{~mL}$ ), but not FC. The absence of FC and the relatively moderate levels of TC and EC are indications that the wastewater channel did not play a significant role in coliform pollution in this well.

Table 3. The fraction of samples with detection of total/fecal coliforms and E. coli for different sample types.

\begin{tabular}{ccccccc}
\hline \multirow{2}{*}{ Type of Sample } & \multicolumn{2}{c}{ Positive for EC (\%) } & \multicolumn{2}{c}{ Positive for FC (\%) } & \multicolumn{2}{c}{ Positive for TC (\%) } \\
\cline { 2 - 6 } & $\mathbf{2 0 1 7}$ & $\mathbf{2 0 1 8}$ & $\mathbf{2 0 1 7}$ & $\mathbf{2 0 1 8}$ & $\mathbf{2 0 1 7}$ & $\mathbf{2 0 1 8}$ \\
\hline River & 100 & 100 & 100 & 100 & 100 & 100 \\
Wastewater channel & 100 & 100 & 100 & 100 & 100 & 100 \\
Household well & 35 & 22 & 90 & 67 & 45 & 33 \\
Other well & 67 & 100 & 100 & 100 & 67 & 100 \\
Water kiosk & 0 & 25 & 25 & 25 & 0 & 25 \\
Tap water & 0 & 0 & 33 & 20 & 17 & 0 \\
Total & 55 & 52 & 83 & 68 & 60 & 55 \\
\hline
\end{tabular}

Coliform concentrations had a strong variance. The concentrations of coliforms in rivers ranged between 4 and 201 MPN for EC, between 3 and 116 MPN for FC, and 53 and 2420 MPN per $100 \mathrm{~mL}$ for TC. Mean values accounted for $43 \mathrm{MPN}(\mathrm{SD}=51 \mathrm{MPN}), 33 \mathrm{MPN}(\mathrm{SD}=33 \mathrm{MPN})$, and $781 \mathrm{MPN}$ (SD = $778 \mathrm{MPN}$ ) per $100 \mathrm{~mL}$ for EC, FC, and TC of river samples.

Coliform concentrations in wells also had a high variance They ranged between 0.1 and 660 MPN for EC, 0.1 and $1350 \mathrm{MPN}$ for FC, and 0.1 and $5794 \mathrm{MPN}$ per $100 \mathrm{~mL}$ for TC. The mean value was $38 \mathrm{MPN}(\mathrm{SD}=129 \mathrm{MPN}$ ) for EC, $59 \mathrm{MPN}(\mathrm{SD}=253 \mathrm{MPN}$ ) for FC, and $550 \mathrm{MPN}$ (SD = $1286 \mathrm{MPN}$ ) per $100 \mathrm{~mL}$ for TC. For further statistical metrics see Table 4 .

The Wilcoxon signed rank test revealed that coliform concentration in river samples were significantly higher than in well samples which was true for EC ( $p$-value $<0.001)$, FC ( $p$-value $<0.001)$, and TC ( $p$-value $<0.001$ ) (Figure 3). 
Table 4. Descriptive statistics of coliform concentrations for E. coli (EC), fecal coliforms (FC), and total coliforms (TC), distinguished between river and well samples. The given p-values are the results of the Wilcoxon singed-rank test.

\begin{tabular}{ccccccc}
\hline \multirow{2}{*}{$\begin{array}{c}\text { Descriptive } \\
\text { Statistics }\end{array}$} & \multicolumn{2}{c}{ EC } & \multicolumn{2}{c}{ FC } & \multicolumn{2}{c}{ TC } \\
\cline { 2 - 7 } & River & Well & River & Well & River & Well \\
\hline $\mathrm{n}$ & 16 & 30 & 16 & 30 & 16 & 30 \\
median & 26.2 & 1.0 & 25.5 & 1.0 & 488.0 & 44.3 \\
mean & 43.3 & 37.9 & 33.1 & 58.5 & 780.6 & 549.6 \\
min & 4.1 & 0.1 & 2.6 & 0.1 & 53.1 & 0.1 \\
max & 200.5 & 660.1 & 115.9 & 1350.0 & 2419.6 & 5794.0 \\
SD & 51.3 & 129.0 & 33.0 & 253.3 & 778.4 & 1286.1 \\
IQR & 34.1 & 6.6 & 38.4 & 5.1 & 516.3 & 288.9 \\
range & 196.4 & 660.0 & 113.4 & 1349.9 & 2366.5 & 5793.9 \\
$p$-value & \multicolumn{2}{c}{$<0.001$} & $<0.001$ & \multicolumn{2}{c}{$<0.001$} \\
\hline
\end{tabular}
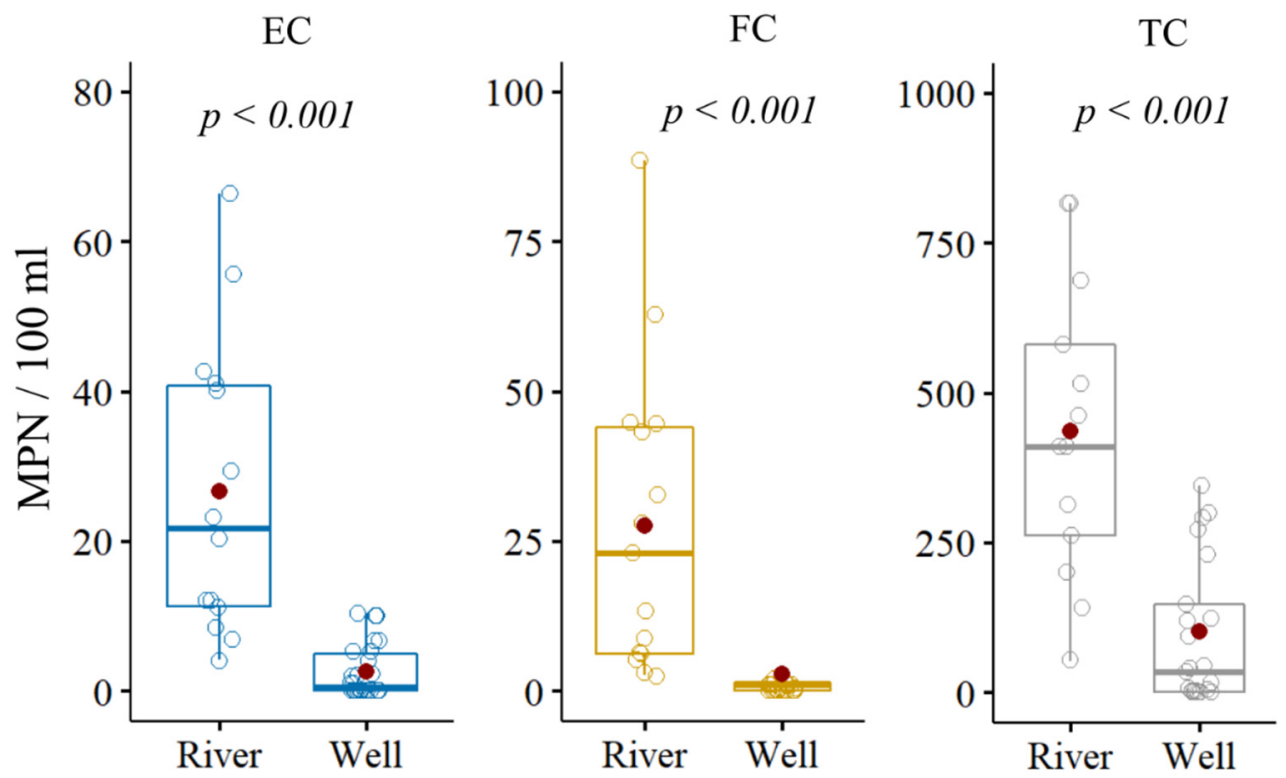

Figure 3. Box plots of coliform concentrations for E. coli (EC), fecal coliforms (FC), and total coliforms (TC). Plots distinguish between river and well samples. Note that outliers were not shown to ensure a better comparison between both groups. Red dots mark the mean value of each population. The given $p$-values are the results of the Wilcoxon signed-rank test to test for significant differences in the mean rank of coliform concentrations between the river and wells. $p$-values smaller than 0.05 indicate a significant difference.

\subsection{Relationship between Temperature and Coliforms in River Samples}

River water samples had a mean temperature of $10.5^{\circ} \mathrm{C}$ with a range between $7.5^{\circ} \mathrm{C}$ and $14.5^{\circ} \mathrm{C}$. Even though warmer samples tended to contain higher concentrations of EC and FC (but not TC) according to the regression analysis (see Figure 4), no statistically significant relationship between water temperature and all three types of coliforms (TC, FC, EC) could be detected (TC: $p=0.23$, FC: $p=0.75$, EC: $p=0.33$ ). The results of the Kendall's $\tau$-Test support these findings (TC: $\tau=-0.25, p=0.19$; EC: $\tau=0.16, p=0.39$; FC: $\tau=0.04, p=0.82$ ). The low slopes of the regression equations provide further indication that for the Kharaa river and its tributaries, the temperature does not appear to be the main driver of coliform concentrations. Nevertheless, it can be noted that the majority of cooler water samples $\left(9^{\circ} \mathrm{C}\right.$ or less) contained very low concentrations of EC and FC and that warmer samples $\left(13^{\circ} \mathrm{C}\right.$ or more) contained some of the highest EC and FC concentrations observed in our samples. 


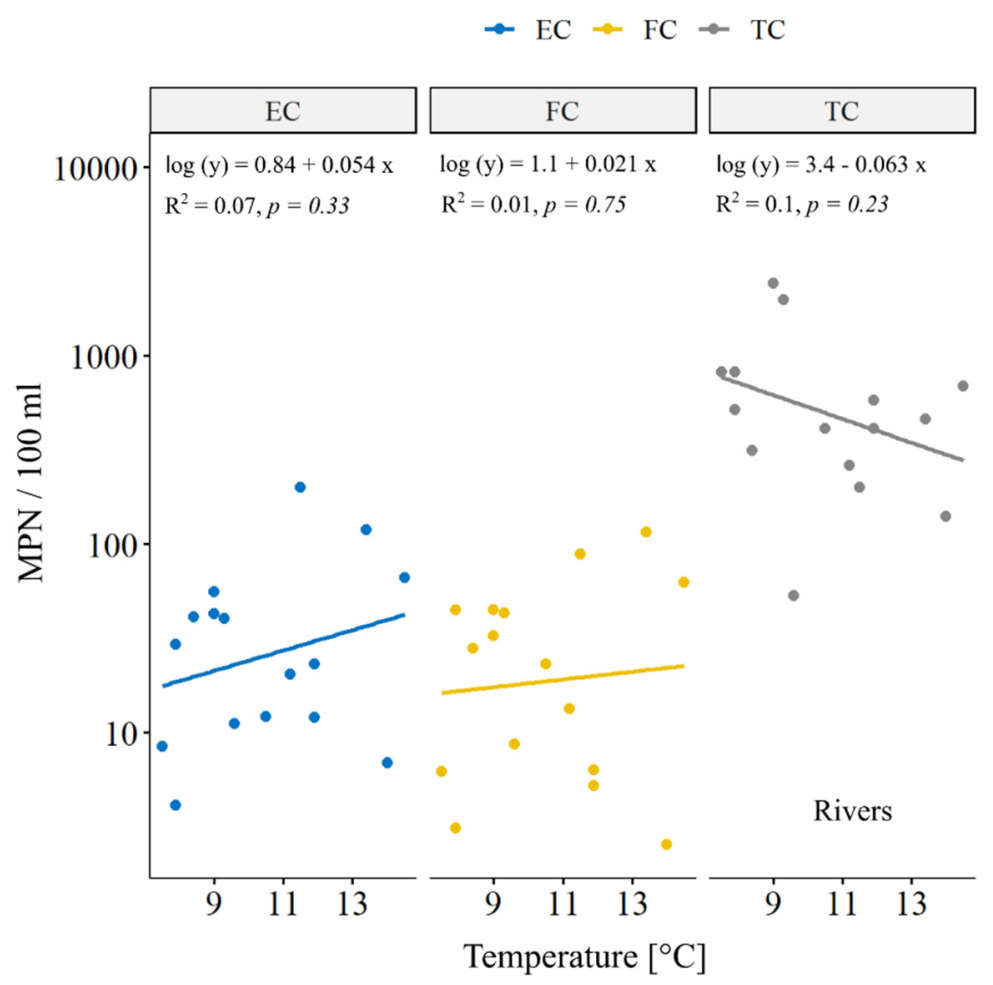

Figure 4. Relationship between temperatures and coliform concentrations in river samples. Please note that the $y$-axis is log-scaled.

\subsection{Relationship between Temperature and Coliforms in Well Samples}

In general, well water samples were cooler and contained lower coliform concentrations than river water samples. Well water samples had a mean temperature of $3.5^{\circ} \mathrm{C}$ (about $7{ }^{\circ} \mathrm{C}$ less than river water samples) with a range between $0.4{ }^{\circ} \mathrm{C}$ and $6.3^{\circ} \mathrm{C}$. A single private well was free from TC, EC, and FC and a small number of (cooler) wells did not contain EC or FC. The most strongly contaminated wells contained concentrations of up to 5794 per $100 \mathrm{~mL}$ for TC, 660 per $100 \mathrm{~mL}$ for EC, and 1350 per $100 \mathrm{~mL}$ for FC (all MPN).

We found a strong positive linear relationship between well water temperatures and log transformed coliform concentrations (TC: $p<0.001$, FC: $p<0.001$; EC: $p<0.001$ ) with positives slopes $(b)$ of $b_{\mathrm{TC}}=0.84, \mathrm{~b}_{\mathrm{FC}}=0.69$, and $\mathrm{b}_{\mathrm{EC}}=0.73$. These findings are supported by a strong positive correlation between all three types of coliform bacteria and temperature (Kendall's $\tau$-Test TC: $\tau=0.52$, $p<0.001$; EC: $\tau=0.63, p<0.001$; FC: $\tau=0.67, p<0.001$ ).

TC was absent in all samples with temperatures up to $1.5^{\circ} \mathrm{C}$ and EC and FC was absent in all samples up to $2.3^{\circ} \mathrm{C}$ (Figure 5). All samples above $2.5^{\circ} \mathrm{C}$ contained TC, whereas all samples above $3.6^{\circ} \mathrm{C}$ contained EC and FC. Between $3.5^{\circ} \mathrm{C}$ and $5.5^{\circ} \mathrm{C}$, coliform concentrations increased by about two orders of magnitude. Moreover, the two warmest samples $\left(5.5^{\circ} \mathrm{C}\right.$ and $\left.6.3^{\circ} \mathrm{C}\right)$ were those that contained the highest concentrations of TC, EC, and FC. Thus, there is multiple evidence supporting the assumption that well water temperature is a good predictor of hygienically relevant microorganisms and their concentrations. 


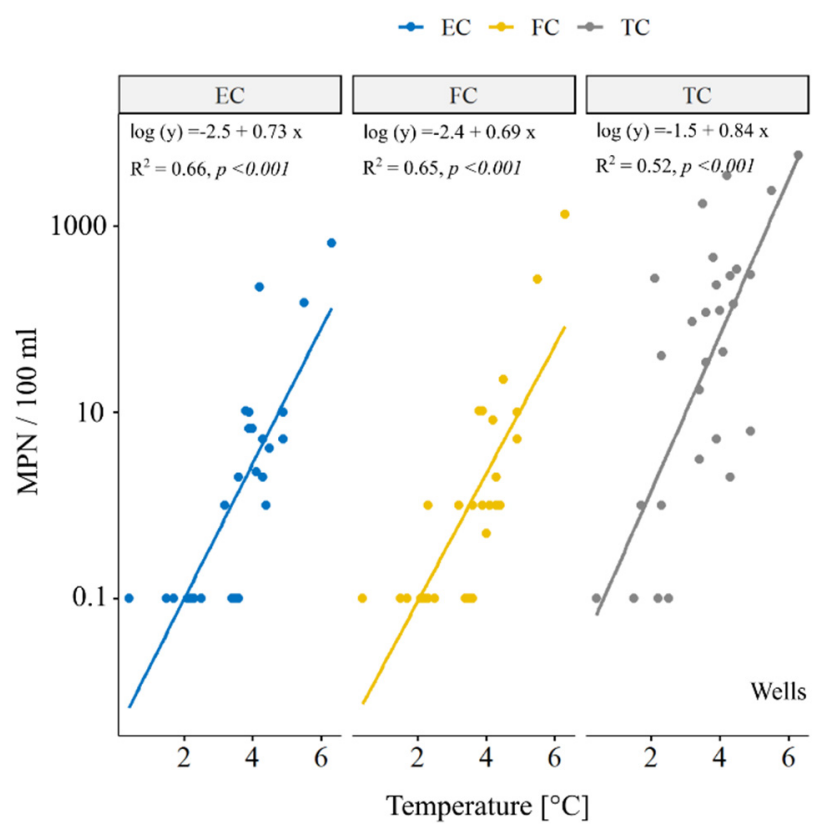

Figure 5. Relationship between temperatures and coliform concentrations in well samples. Please note that the $y$-axis is log-scaled.

\section{Discussion}

River water samples along the Kharaa River Basin would, according to international classifications for surface water hygiene, be considered lightly to moderately polluted [53]. However, the specific situation in Mongolia that surface water bodies are not only used by animals but sometimes also as sources of domestic (drinking) water necessitate the comparison to drinking water standards. This is even more true for wells, which often have various domestic water usage as their primary purpose. When comparing the data to international guidelines and the Mongolian drinking water standard in particular [54], it is alarming to see that a large number of water sources contain hygienically relevant impurities. The fact that in some cases even fecal coliforms could be detected in improved water sources (tap water, water commercially sold at water kiosks), raises serious concerns about their hygienic safety, despite the fact that these sources were found to be much safer than untreated surface or well water. Despite these problems, well water samples contained significantly lower concentrations of TC, EC, and FC than river water samples, making them the relatively safer option among the two water sources.

It should be noted that all of the mentioned water sources except for the treated wastewater are used for drinking or food preparation by some parts of the population, and even the treated wastewater effluent is accessible to livestock (cows were present in and around the effluent stream on all sampling days). When asked, local residents often stated that they would not use well water for drinking purposes. However, one local resident in Tunkhel drank water straight from his well during our sampling campaign-despite mentioning water kiosks as the only source of his family's drinking water. This example illustrates that the mere presence of microbiologically contaminated wells located on private property constitutes at least some risk.

The investigation of linkages between water temperatures and the hygienic quality of the river and well water samples in the Kharaa River Basin showed weak and non-significant correlations for river water, but moderate and significant correlations for well water. Even though it is obvious that temperature is not the only factor governing the hygienic quality of surface water and wells, it is noteworthy that the warmest samples of each type contained the highest concentrations of bacteria, with the only exception being TC in river water. The weaker and non-significant correlations between temperature and coliform concentrations in river water are not very surprising. On the one hand, 
microbiological pollution rates in both rivers and wells depend on pollutant inputs, e.g., through wastewater discharge, livestock, and unsealed latrines. However, in the case of rivers, their discharge, other water quality parameters (e.g., nutrient concentration), and self-purification rates (e.g., through UV disinfection) play major roles and can lead to strong temporal differences [55-58]. In the case of wells, their construction (e.g., sealing) and depth play a major role. Within our study region, wells had poor to no sealing at all, and their depths ranged between $5 \mathrm{~m}$ and $10 \mathrm{~m}$ only; much deeper wells, as are used for the supply of some water kiosks or for urban water supply systems were not considered in our study. This explains why temperatures played a much greater role in coliform concentrations.

The observed warming in the Kharaa River Basin (more than $+2{ }^{\circ} \mathrm{C}$ since 1940) and the predicted acceleration in this warming trend is likely to have significant impacts on the hygienic quality of unimproved water sources, particularly simple wells. In several parts of the world, it has been shown that the seasonality or change of climate affects not only surface but also groundwater temperatures up to a depth of about 10 to $15 \mathrm{~m}$ [59]. Observations have shown temperature increases in shallow groundwater that were approximately half of the increase in atmospheric temperature or even more [60]. Particularly for shallow wells as those found in the study region, observations during spring showed that a 1 to $2{ }^{\circ} \mathrm{C}$ increase in temperature is likely to lead to an increase of TC, EC, and FC concentrations by one to two orders of magnitude. Even though the observed increase was far smaller and not statistically significant for river water, increasing temperatures would most likely also lead to increasing concentrations of EC and FC. Besides these temperature changes, it should be noted that significant changes in rainfall patterns have been described for Mongolia [27]. The trend towards short but very strong rainfall events is likely to transport the almost omnipresent animal feces into surface waters and shallow wells with limited or no sealing, further adding to the hygienic risks. Severe outbreaks of waterborne diseases in several other regions of the world have been linked to extreme hydrometeorological events. A particularly notable incident occurred in Milwaukee, USA in 1993, where cryptosporidium cysts entered Lake Michigan and subsequently the municipal water supply system, leading to more than 400,000 infections and 54 deaths [61,62]. In Walkerton, Canada, unusually strong rainfall washed enterohemorrhagic E. coli (EHEC) and Campylobacter jejuni into shallow wells of the municipal water supply company in 2000 [30]. In Europe, strong rainfall events have been linked to the contamination of water supply systems by several types of bacteria, protozoa, and viruses $[31,63,64]$. These examples illustrate that the trend towards stronger rainfall events in Mongolia may become problematic from a water supply and public health perspective unless suitable precautions are taken.

\section{Conclusions}

The case study on linkages between temperature and hygienic quality of surface and shallow groundwater sources in the Kharaa River Basin, Mongolia revealed that temperature is one of the factors that govern the concentration of coliform bacteria. Particularly with regard to wells, the predicted increase in temperature of at least $2.6^{\circ} \mathrm{C}$ by the end of the 21 st century as compared to the end of the 20th century means that coliform concentrations in small wells are likely to increase by one to two orders of magnitude. Since these wells are used not only for livestock and irrigation purposes of small-scale agriculture but often also for food preparation or even human consumption, local adaptation measures to global warming must include the provision of safe and affordable alternatives as well as awareness-raising among the local population. In the future, the findings of the present study should be corroborated by further research (including modeling) that takes into account different times of the year as well as the impacts of strong rainfall events, which did not occur during the two sampling periods described here. Despite its limitations, this study confirms current review studies on the climate change impacts on water hygiene [13-23] and provides a first empirically-based discussion for its case study region in Mongolia.

Author Contributions: Conceptualization, D.K.; methodology, K.W., D.K. and A.T.; validation, A.T., B.-E.O. and K.W.; formal analysis, D.K., K.W., B.-E.O., A.T.; investigation, K.W., B.-E.O., A.T. and D.K.; resources, A.T., D.K.; data curation, B.-E.O.; writing-original draft preparation, A.T., B.-E.O. and D.K; writing-review and 
editing, D.K., K.W.; visualization, D.K.; supervision, D.K.; project administration, D.K.; funding acquisition, D.K. All authors have read and agreed to the published version of the manuscript.

Funding: This research was funded by the German Federal Ministry of Education and Research, grant number 033L003, and the German Academic Exchange Service via their institutional support to GMIT.

Conflicts of Interest: The authors declare no conflict of interest. The funders had no role in the design of the study; in the collection, analyses, or interpretation of data; in the writing of the manuscript, or in the decision to publish the results.

\section{References}

1. United Nations. The Sustainable Development Goals Report; United Nations: New York, NY, USA, 2020.

2. Mongolian National CSOs Network on SDGs. Mongolian Civil Society Joint Report on Implementation of Sustainable Development Goals; Mongolian National CSOs Network on SDGs: Ulaanbaatar, Mongolia, 2019.

3. Davgasuren, B.; Nyam, S.; Altangerel, T.; Ishdorj, O.; Amarjargal, A.; Choi, J.Y. Evaluation of the trends in the incidence of infectious diseases using the syndromic surveillance system, early warning and response unit, Mongolia, from 2009 to 2017: A retrospective descriptive multi-year analytical study. BMC Infect. Dis. 2019, 19, 705. [CrossRef]

4. Sorokovikova, L.M.; Popovskaya, G.I.; Tomberg, I.V.; Sinyukovich, V.N.; Kravchenko, O.S.; Marinaite, I.I.; Bashenkhaeva, N.V.; Khodzher, T.V. The Selenga River water quality on the border with Mongolia at the beginning of the 21st century. Russ. Meteorol. Hydrol. 2013, 38, 126-133. [CrossRef]

5. Uddin, S.; Zifu, L.; Gaillard, J.C.; Tedoff, P.F.; Mang, H.P.; Lapegue, J.; Huba, E.M.; Kummel, O.; Rheinstein, E. Exposure to WASH-borne hazards: A scoping study on peri-urban Ger areas in Ulaanbaatar, Mongolia. Habitat Int. 2014, 44, 403-411. [CrossRef]

6. Ebright, J.; Altantsetseg, T.; Oyungerel, R. Emerging Infectious Diseases in Mongolia. Emerg. Infect. Dis. 2003, 9, 1509-1515. [CrossRef] [PubMed]

7. Karthe, D.; Sigel, K.; Scharaw, B.; Stäudel, J.; Hufert, F.; Borchardt, D. Towards an integrated concept for monitoring and improvements in water supply, sanitation and hygiene (WASH) in urban Mongolia. Water Risk 2012, 20, 1-5.

8. Sigel, K.; Altantuul, K.; Basandorj, D. Household needs and demand for improved water supply and sanitation in peri-urban ger areas: The case of Darkhan, Mongolia. Environ. Earth Sci. 2012, 65, 1561-1566. [CrossRef]

9. Oyunchimeg, M.; Burmaajav, B.; Enkhjargal, A.; Tsegmed, S.; Suvd, B.; Oyun-Erdene, O.; Zolzaya, D.; Otgonbayar, D.; Oyunchimeg, D.; Azjargal, L.; et al. Soil Microbial Contamination And Its Impact On Child Diarrheal Disease Incidence In Ulaanbaatar. Geogr. Environ. Sustain. 2019, 12, 243-251. [CrossRef]

10. Foggin, P.; Farkas, O.; Shiirev-Adiya, S.; Chinbat, B. Health Status and Risk Factors of Seminomadic Pastoralists in Mongolia: A Geographical Approach. Soc. Sci. Med. 1997, 44, 1623-1647. [CrossRef]

11. Karthe, D.; Londong, J.; Reeh, T.; Hufert, F. Wassermanagement in mongolischen Tourist Ger Camps: Status Quo und Herausforderungen. Z. Tour. 2013, 5, 215-221. (In German)

12. Malsy, M.; Flörke, M.; Borchardt, D. What drives the water quality changes in the Selenga Basin: Climate change or socio-economic development? Reg. Environ. Chang. 2016, 17, 1977-1989. [CrossRef]

13. Cho, K.H.; Pachepsky, Y.A.; Kim, M.; Pyo, J.; Park, M.H.; Kim, Y.M.; Kim, J.W.; Kim, J.H. Modeling seasonal variability of fecal coliform in natural surface waters using the modified SWAT. J. Hydrol. 2016, 535, 377-385. [CrossRef]

14. Hong, H.; Qiu, J.; Liang, Y. Environmental factors influencing the distribution of total and fecal coliform bacteria in six water storage reservoirs in the Pearl River Delta Region, China. J. Environ. Sci. 2010, 22, 663-668. [CrossRef]

15. St Laurent, J.; Mazumder, A. Influence of seasonal and inter-annual hydro-meteorological variability on surface water fecal coliform concentration under varying land-use composition. Water Res. 2014, 48, 170-178. [CrossRef]

16. Cha, S.M.; Lee, S.W.; Park, Y.E.; Cho, K.H.; Lee, S.; Kim, J.H. Spatial and temporal variability of fecal indicator bacteria in an urban stream under different meteorological regimes. Water Sci. Technol. 2010, 61, 3102-3108. [CrossRef] [PubMed] 
17. Islam, M.M.M.; Hofstra, N.; Islam, M.A. The Impact of Environmental Variables on Faecal Indicator Bacteria in the Betna River Basin, Bangladesh. Environ. Processes 2017, 4, 319-332. [CrossRef]

18. Howard, G.; Calow, R.; Macdonald, A.; Bartram, J. Climate Change and Water and Sanitation: Likely Impacts and Emerging Trends for Action. Ann. Rev. Environ. Resour. 2016, 41, 253-276. [CrossRef]

19. Carlton, E.J.; Woster, A.P.; DeWitt, P.; Goldstein, R.S.; Levy, K. A systematic review and meta-analysis of ambient temperature and diarrhoeal diseases. Int. J. Epidemiol. 2015, 45, 117-130. [CrossRef] [PubMed]

20. Philipsborn, R.; Ahmed, S.M.; Bsrosi, B.J.; Levy, K. Climatic drivers of diarrheagenic Escherichia coli incidence: A systematic review and meta-analysis. J. Infect. Dis. 2016, 214, 6-15. [CrossRef] [PubMed]

21. Levy, K.; Woster, A.P.; Goldstein, R.S.; Carlton, E.J. Untangling the Impacts of Climate Change on Waterborne Diseases: A Systematic Review of Relationships between Diarrheal Diseases and Temperature, Rainfall, Flooding, and Drought. Environ. Sci. Technol. 2016, 50, 4905-4922. [CrossRef] [PubMed]

22. El-Fadel, M.; Ghanimeh, S.; Maroun, R.; Alameddine, I. Climate change and temperature rise: Implications on food- and water-borne diseases. Sci. Total Environ. 2012, 437, 15-21. [CrossRef]

23. Funari, E.; Manganelli, M.; Sinisi, L. Impact of climate change on waterborne diseases. Ann. Inst. Super. Sanità 2012, 48, 473-487. [CrossRef] [PubMed]

24. Hofmann, J.; Hürdler, J.; Ibisch, R.; Schaeffer, M.; Borchardt, D. Analysis of Recent Nutrient Emission Pathways, Resulting Surface Water Quality and Ecological Impacts under Extreme Continental Climate: The Kharaa River Basin (Mongolia). Int. Rev. Hydrobiol. 2011, 96, 484-519. [CrossRef]

25. Malsy, M.; aus der Beek, T.; Flörke, M. Evaluation of large-scale precipitation data sets for water resources modelling in Central Asia. Environ. Earth Sci. 2015, 73, 787-799. [CrossRef]

26. Unger-Shayesteh, K.; Vorogushyn, S.; Merz, B.; Frede, H.G. Introduction to Water in Central Asia-Perspectives under global change. Glob. Planet. Chang. 2013, 110, 1-152. [CrossRef]

27. Vandandorj, S.; Munkhjargak, E.; Boldgiv, B.; Gantsetseg, B. Changes in event number and duration of rain types over Mongolia from 1981 to 2014. Environ. Earth Sci. 2017, 76, 70. [CrossRef]

28. Krüger, E.; Rao, S.P.; Borchardt, D. Quantifying urban water supply security under global change. Glob. Environ. Chang. 2019, 56, 66-74. [CrossRef]

29. Kopp, B.; Lange, J.; Menzel, L. Effects of wildfire on runoff generating processes in northern Mongolia. Reg. Environ. Chang. 2017, 17, 1951-1963. [CrossRef]

30. Auld, H.; MacIver, D.; Klaassen, J. Heavy rainfall and waterborne disease outbreaks: The Walkerton example. J. Toxicol. Environ. Health A 2004, 67, 1879-1887. [CrossRef]

31. Karthe, D. Bedeutung hydrometeorologischer Extremereignisse im Kontext des Klimawandels für die Trinkwasserhygiene in Deutschland und Mitteleuropa. Hydrol. Wasserbewirtsch. 2015, 59, $264-270$. (In German) [CrossRef]

32. Tornevi, A.; Bergstedt, O.; Forsberg, B. Precipitation Effects on Microbial Pollution in a River: Lag Structures and Seasonal Effect Modification. PLoS ONE 2014, 9, e98546. [CrossRef]

33. Karthe, D.; Chalov, S.; Moreydo, V.; Pashkina, M.; Romanchenko, A.; Batbayar, G.; Kalugin, A.; Westphal, K.; Malsy, M.; Flörke, M. Assessment and Prediction of Runoff, Water and Sediment Quality in the Selenga River Basin aided by a Web-Based Geoservice. Water Resour. 2017, 44, 399-416. [CrossRef]

34. Kasimov, N.; Karthe, D.; Chalov, S. Environmental change in the Selenga River-Lake Baikal Basin. Reg. Environ. Chang. 2017, 17, 1945-1949. [CrossRef]

35. Heldt, S.; Rodriguez, J.C.; Dombrowsky, I.; Feld, C.; Karthe, D. Is the EU WFD suitable to support IWRM Planning in non-European countries? Lessons Learnt from the Introduction of IWRM and River Basin Management in Mongolia. Environ. Sci. Pol. 2017, 75, 27-37. [CrossRef]

36. Menzel, L.; Hofmann, J.; Ibisch, R. Untersuchung von Wasser- und Stoffflüssen als Grundlage für ein Integriertes Wasserressourcen-Management im Kharaa-Einzugsgebiet (Mongolei). Hydrol. Wasserbewirtsch. 2011, 55, 88-103.

37. Karthe, D.; Heldt, S.; Rost, G.; Londong, J.; Ilian, J.; Heppeler, J.; Khurelbaatar, G.; Sullivan, C.; van Afferden, M.; Stäudel, J.; et al. Modular Concept for Municipal Waste Water Management in the Kharaa River Basin, Mongolia. In Integrated Water Resources Management: Concept, Research and Implementation; Borchardt, D., Bogardi, J., Ibisch, R., Eds.; Springer: Heidelberg, Germany; New York, NY, USA, 2016; pp. 649-681.

38. Karthe, D.; Westphal, K. Water and hygiene in the Kharaa River Basin, Mongolia: Current knowledge and research needs. Geogr. Environ. Sustain. 2017, 10, 44-53. [CrossRef] 
39. Ochirbold, B.E. Hygienic Assessment of Surface, Ground and Drinking Water in the Kharaa River Basin. Bachelor's Thesis, German-Mongolian Institute for Resources and Technology, Ulaanbaatar, Mongolia, 2018.

40. Angerer, J.; Han, G.; Fujisaki, I.; Havstad, K. Climate Change and Ecosystems of Asia with Emphasis on Inner Mongolia and Mongolia. Rangelands 2008, 30, 46-51. [CrossRef]

41. Pan, C.G.; Pope, A.; Kamp, U.; Dashtseren, A.; Walther, M.; Syromyatina, M.V. Glacier recession in the Altai Mountains of Mongolia in 1990-2016. Geogr. Ann. A 2018, 100, 185-203. [CrossRef]

42. Sharkhuu, A.; Sharkhuu, N.; Etzelmüller, B.; Heggem, E.S.F.; Nelson, F.E.; Shiklomanov, N.I.; Goulden, C.E.; Brown, J. Permafrost monitoring in the Hovsgol mountain region, Mongolia. J. Geophys. Res. 2007, 102, F02S06. [CrossRef]

43. Safronov, A.N. Effects of Climatic Warming and Wildfires on Recent Vegetation Changes in the Lake Baikal Basin. Climate 2020, 8, 57. [CrossRef]

44. Rao, M.P.; Davi, N.K.; D’Arrigo, R.D.; Skees, J.; Nachin, B.; Leland, C.; Lyon, B.; Wang, S.Y.; Byambasuren, O. Dzuds, droughts, and livestock mortality in Mongolia. Environ. Res. Lett. 2015, 10, 074012. [CrossRef]

45. Sternberg, T. Investigating the presumed causal links between drought and dzud in Mongolia. Nat. Hazards 2018, 92, 27-43. [CrossRef]

46. Kistemann, T.; Classen, T.; Koch, C.; Dangendorf, F.; Fischeder, R.; Gebel, J.; Vacata, V.; Exner, M. Microbial load of drinking water reservoir tributaries during extreme rainfall and runoff. Appl. Environ. Microbiol. 2002, 68, 2188-2197. [CrossRef]

47. Mälzer, H.J.; aus der Beek, T.; Müller, S.; Gebhardt, J. Comparison of different model approaches for a hygiene early warning system at the lower Ruhr River, Germany. Int. J. Hyg. Environ. Health 2016, 219, 671-680. [CrossRef] [PubMed]

48. Reder, K.; Flörke, M.; Alcamo, J. Modeling historical fecal coliform loadings to large European rivers and resulting in-stream concentrations. Environ. Model. Softw. 2015, 63, 251-263. [CrossRef]

49. Kaeseberg, T.; Schubert, S.; Oertel, R.; Zhang, J.; Berendonk, T.U.; Krebs, P. Hot spots of antibiotic tolerant and resistant bacterial subpopulations in natural freshwater biofilm communities due to inevitable urban drainage system overflows. Environ. Pollut. 2018, 242, 164-170. [CrossRef] [PubMed]

50. Rompré, A.; Servais, P.; Baudart, J.; de-Roubin, M.R.; Laurent, P. Detection and enumeration of coliforms in drinking water: Current methods and emerging approaches. J. Microbiol. Methods 2002, 49, 31-54. [CrossRef]

51. Pitkänen, T.; Paakkari, P.; Miettinen, I.T.; Heinonen-Tanski, H.; Paulin, L.; Hänninen, M.L. Comparison of media for enumeration of coliform bacteria and Escherichia coli in non-disinfected water. J. Microbiol. Methods 2007, 68, 522-529. [CrossRef]

52. R Core Team. R: A Language and Environment for Statistical Computing; R Foundation for Statistical Computing: Vienna, Austria, 2018.

53. Kirschner, A.K.T.; Kavka, G.G.; Velimirov, B.; Mach, R.L.; Sommer, R.; Farnleitner, A.H. Microbiological water quality along the Danube River: Integrating data from two whole-river surveys and a transnational monitoring network. Water Res. 2009, 43, 3673-3684. [CrossRef] [PubMed]

54. Mongolian Drinking Water Standard MNS 0900:2018. Available online: http://estandard.gov.mn/standard/v/ 4763 (accessed on 24 September 2020).

55. Karthe, D.; Lin, P.Y.; Westphal, K. Gradients of Water Hygiene in the Holtemme, a Small Headwater Stream in the Elbe River Basin, Northern Germany. Front. Earth Sci. 2017, 11, 544-553. [CrossRef]

56. Bagde, U.S.; Rangari, A.K. Periodicity of coliform bacteria in an aquatic environment. Water Sci. Technol. 1999, 40, 151-157. [CrossRef]

57. Tiefenthaler, L.; Stein, E.; Lyon, G. Fecal indicator bacteria (FIB) levels during dry weather from Southern California reference streams. Environ. Monit. Assess. 2009, 155, 477-492. [CrossRef]

58. Shelton, D.R.; Pachepsky, Y.A.; Kiefer, L.A.; Blaustein, R.A.; McCarty, G.W.; Dao, T.H. Response of coliform populations in streambed sediment and water column to changes in nutrient concentrations in water. Water Res. 2014, 59, 316-324. [CrossRef] [PubMed]

59. Taylor, C.A.; Stefan, H.G. Shallow groundwater temperature response to climate change and urbanization. J. Hydrol. 2009, 375, 601-612. [CrossRef]

60. Menberg, K.; Blum, P.; Kurylyk, B.L.; Bayer, P. Observed groundwater temperature response to recent climate change. Hydrol. Earth Syst. Sci. 2014, 18, 4453-4466. [CrossRef] 
61. Hoxie, N.J.; Davis, J.P.; Vergeront, J.M.; Nashold, R.D.; Blair, K.A. Cryptosporidiosis-associated mortality following a massive waterborne outbreak in Milwaukee, Wisconsin. Am. J. Public Health 1997, 87, 2032-2035. [CrossRef] [PubMed]

62. Mac Kenzie, W.R.; Hoxie, N.J.; Proctor, M.E.; Gradus, M.S.; Blair, K.A.; Peterson, D.E.; Kazmierczak, J.J.; Addiss, D.G.; Fox, K.R.; Rose, J.B.; et al. A massive outbreak in Milwaukee of cryptosporidium infection transmitted through the public water supply. N. Engl. J. Med. 1994, 331, 161-167. [CrossRef]

63. Cann, K.F.; Thomas, D.R.; Salmon, R.L.; Wyn-Jones, A.P.; Kay, D. Extreme water-related weather events and waterborne disease. Epidemiol. Infect. 2013, 141, 671-686. [CrossRef] [PubMed]

64. Nichols, G.; Lane, C.; Asgari, N.; Verlander, N.Q.; Charlett, A. Rainfall and outbreaks of drinking water related disease in England and Wales. J. Water Health 2009, 7, 1-8. [CrossRef] [PubMed]

Publisher's Note: MDPI stays neutral with regard to jurisdictional claims in published maps and institutional affiliations.

(C) 2020 by the authors. Licensee MDPI, Basel, Switzerland. This article is an open access article distributed under the terms and conditions of the Creative Commons Attribution (CC BY) license (http://creativecommons.org/licenses/by/4.0/). 